\title{
PENGARUH PROFITABILITAS, LIKUIDITAS DAN KEBIJAKAN DIVIDEN TERHADAP NILAI PERUSAHAAN MANUFAKTUR YANG TERDAFTAR DI BURSA EFEK INDONESIA (BEI)
}

\author{
*Richa Ayu Alifiani, Sutopo, Indah Noviandari \\ Prodi Manajemen Fakultas Ekonomi dan Bisnis \\ Universitas Bhayangkara Surabaya, Indonesia
}

DOI: $10.46821 /$ ekobis.v1i1.1

\begin{abstract}
ABSTRAK
Penelitian ini bertujuan untuk membuktikan dan menganalisis pengaruh profitabilitas, likuiditas dan kebijakan dividen secara simultan dan parsial terhadap nilai perusahaan manufaktur yang terdaftar di Bursa Efek Indonesia (BEI). Teknik analisis data pada penelitian ini menggunakan bantuan SPSS. Pengujian data yang digunakan adalah analisis regresi linier berganda. Hasil penelitian menunjukkan bahwa variabel Profitabilitas dan Likuiditas berpengaruh signifikan terhadap Nilai Perusahaan. Sedangkan Kebijakan Dividen tidak berpengaruh signifikan terhadap Nilai Perusahaan. Hasil dari pengujian regresi dapat disimpulkan bahwa variabel Profitabilitas yang berpengaruh dominan terhadap Nilai Perusahaan.
\end{abstract}

Kata Kunci: Profitabilitas, Likuiditas, Kebijakan Dividen, Nilai Perusahaan.

\begin{abstract}
This study aims to verify and analyze the effect of profitability, liquidity and dividend policy simultaneously and partially on the firm value listed on Indonesia Stock Exchange. The data analysis technique in this study using SPSS. The test of data used multiple linear regression analysis. The result showed that the variable Profitability and Liquidity have a significant effect on the Firm Value. While the dividend policy does not influence significantly for the Firm Value. The result of the regression test can be concluded that the variable profitability dominant influence on the Firm Value.
\end{abstract}

Keywords : Profitability, Likuidity, Dividend Policy, Firm Value

\section{PENDAHULUAN}

Bursa Efek Indonesia merupakan gabungan dari Bursa Efek atau pasar modal yaitu Bursa Efek Jakarta (Jakarta Stock Exchange) dan Bursa Efek Surabaya (Surabaya Stock Exchange). Prospek pertumbuhan pasar modal di Indonesia semakin pesat karena didorong oleh banyaknya minat dari para investor asing yang masuk ke pasar modal Indonesia. Di Bursa Efek Indonesia (BEI) terdapat banyak perusahaan manufaktur yang telah terdaftar. Perusahaan manufaktur adalah suatu badan usahan yang kegiatan operasionalnya menggunakan mesin, peralatan serta tenaga kerja dalam suatu proses untuk mengubah bahan mentah menjadi barang jadi yang memiliki nilai jual. 
Terjadinya pertumbuhan sektor industri manufaktur yang fluktuatif di Indonesia pada setiap tahunnya. Karena pertumbuhan sektor industri yang maju atau meningkat di Indonesia dapat mempengaruhi finansial di Indonesia agar lebih unggul dalam persaingan. Untuk meningkatkan Nilai Perusahaan maka perlu mengetahui faktor-faktor apa saja yang mempengaruhinya. Adapun faktor-faktor yang mempengaruhi Nilai Perusahaan adalah Profitabilitas, Likuiditas dan Kebijakan Dividen. Berdasarkan uraian diatas, maka penulis tertarik untuk melakukan penelitian sebagai tugas akhir dengan judul:Pengaruh Profitabiltas, Likuiditas dan Kebijakan Dividen Terhadap Nilai Perusahaan Manufaktur Yang Terdaftar Di Bursa Efek Indonesia (BEI).

\section{TINJAUAN PUSTAKA \\ Profitabilitas}

Menurut Dewi dan Badjra dalam Erawati dan Sulistiyanto (2019) menyatakan bahwa perusahaan percaya bahwa investor dalam pengambilan keputusan invesor akan melihat kemampuan perusahaan dalam perolehan laba yang tinggi lebih mampu untuk meningkatkan kemakmuran dari pemegang saham. Semakin tinggi laba yang dihasilkan oleh perusahaan maka semakin tinggi harga saham sehingga meningkatkan nilai perusahaan. Sedangkan Hanafi dan Halim (2016) mendefinisikan profitabilitas adalah rasio yang mengukur kemampuan perusahaan menghasilkan keuntungan (profitabilitas) pada tingkat penjualan aset dan modal saham yang tertentu.

\section{Likuiditas}

Likuiditas adalah rasio yang digunakan untuk mengukur kemampuan perusahaan dalam memenuhi kewajiban keuangan jangka pendek yang berupa hutang-hutang jangka pendek. Rasio ini ditunjukkan dari besar kecilnya aktiva lancar. Seberapa cepat (likuid) perusahaan memenuhi kinerja keuangannya, umumnya kewajiban jangka pendek (kewajiban kurang dari satu periode/tahun) (Sujarweni, 2017).

\section{Kebijakan Dividen}

Kebijakan dividen adalah kebijakan mengenai keputusan yang diambil perusahaan tentang bagaimana tingkat laba yang diperoleh perusahaan akan dibagikan kepada pemegang saham sebagai dividen atau ditahan dalam bentuk laba ditahan yang nantinya digunakan untuk membiayai investasi perusahaan dimasa yang akan datang. Kebijakan mengenai jumlah besaran dividen yang akan dibagikan kepada para pemegang saham sangat mempengaruhi investor dalam niatnya untuk menanamkan modalnya di dalam perusahaan. Sedangkan, laba yang ditahan merupakan salah satu sumber dana untuk membiayai pertumbuhan perusahaan, semakin baik pengelolaan pembiayaan perusahaan yang berasal dari laba ditahan semakin kuat pula posisi financial perusahaan tersebut. Nantinya laba ditahan ini dijadikan sebuah investasi oleh perusahaan, dan dipergunakan untuk membiayai operasi perusahaan dimasa mendatang (Susila dan Prena, 2019).

\section{Nilai Perusahaan}

Nilai Perusahaan adalah persepsi investor terhadap keberhasilan perusahaan dalam suatu periode. Keberhasilan tersebut dapat dilihat dari pergerakan harga saham. Dengan nilai perusahaan yang bagus akan dapat menarik minat eksternal perusahaan untuk menanamkan modal diperusahaan tersebut. Nilai perusahaan ini 
nantinya dijadikan suatu indikator penting oleh investor dalam menentukan pilihan apakah dia akan menanamkan modalnya atau tidak (Susila dan Prena, 2019). Sedangkan menurut Husnan dalam Manoppo dan Arie (2016) menyatakan bahwa nilai perusahaan atau juga disebut dengan nilai pasar perusahaan merupakan harga yang bersedia dibayar oleh calon pembeli apabila perusahaan tersebut dijual.

\section{METODE PENELITIAN}

\section{Populasi}

Populasi dalam penelitian ini adalah perusahaan manufaktur yang terdaftar di Bursa Efek Indonesia (BEI) yang memiliki jumlah populasi 131 perusahaan tetapi tidak semua populasi ini akan menjadi objek penelitian.

\section{Sampel}

Dalam penelitian ini menggunakan 15 sampel perusahaan sektor manufaktur yang terdaftar di Bursa Efek Indonesia (BEI), menggunakan 60 sampel laporan keuangan selama 4 periode, yaitu dari tahun 2015 sampai tahun 2018.

\section{Kerangka Konseptual}

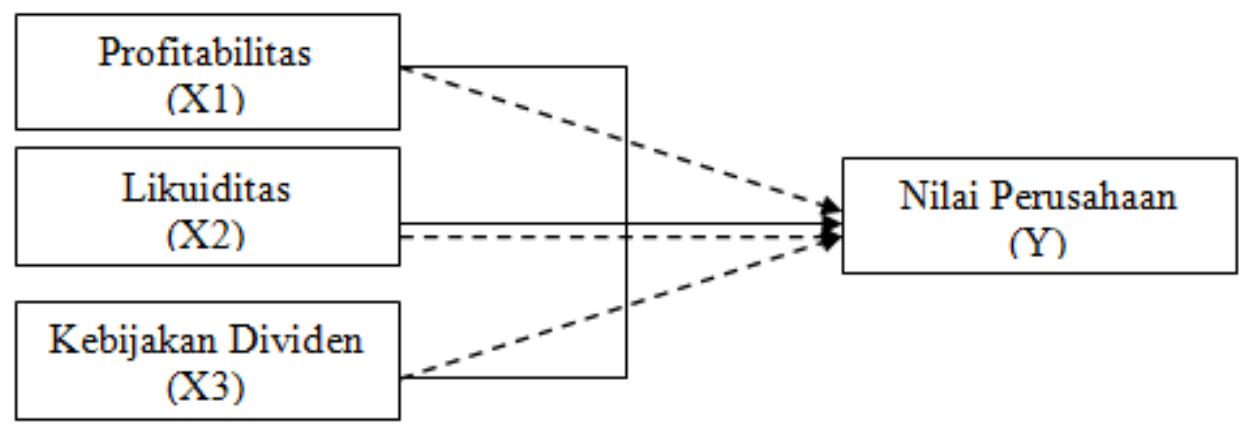

Sumber: Peneliti (2019)

Gambar 1

Kerangka Konseptual Penelitian

\section{Hipotesis Penelitian}

Berdasarkan pokok masalah yang dirumuskan serta tujuan penelitian, kemudian diperkuat pada kajian teoritis sebagaimana diuraikan diatas, maka selanjutnya dapat diajukan hipotesis penelitian sebagai berikut:

1. Bahwa variabel Profitabilitas, Likuiditas, dan Kebijakan Dividen berpengaruh secara simultan terhadap Nilai Perusahaan manufaktur yang terdaftar di Bursa Efek Indonesia (BEI).

2. Bahwa variabel Profitabilitas, Likuiditas, dan Kebijakan Dividen berpengaruh secara parsial terhadap Nilai Perusahaan manufaktur yang terdaftar di Bursa Efek Indonesia (BEI).

3. Bahwa variabel Profitabilitas berpengaruh secara dominan terhadap Nilai Perusahaan manufaktur yang terdaftar di Bursa Efek Indonesia (BEI). 
Tabel 1

Analisis Regresi Linier Berganda

\begin{tabular}{lllll}
\hline Model & $\begin{array}{l}\text { Unstandardized } \\
\text { Coefficients }\end{array}$ & $\begin{array}{l}\text { Standardized } \\
\text { Coefficients }\end{array}$ & t & Sig. \\
\cline { 2 - 5 }
\end{tabular}

\begin{tabular}{|c|c|c|c|c|c|c|}
\hline & & B & Std. Error & Beta & B & Std. Error \\
\hline \multirow[t]{4}{*}{1} & (Constant) & 9,234 & 3,998 & & 2,310 & ,025 \\
\hline & Profitabilitas & 44,157 & 11,278 & 446 & 3,915 & ,000 \\
\hline & Likuiditas & $-5,447$ & 1,743 &,- 332 & $-3,124$ & ,003 \\
\hline & $\begin{array}{l}\text { Kebijakan } \\
\text { Dividen }\end{array}$ & 7,149 & 4,245 & 192 & 1,684 & 098 \\
\hline
\end{tabular}

Sumber: Peneliti (2019)

\section{Lokasi dan Waktu Penelitian}

1. Lokasi Penelitian

Lokasi dimana penelitian ini dilakukan adalah Bursa Efek Indonesia (BEI) di Surabaya.

2. Waktu Penelitian

Waktu penelitian dilaksanakan pada bulan April 2019 hingga terselesaikannya penelitian.

\section{Jenis dan Sumber Data}

a. Jenis Data

Data yang digunakan dalam penelitian ini, baik yang bertujuan untuk mendiskripsikan maupun untuk menganalisis, diperoleh dari data sekunder. Data sekunder adalah data yang diperoleh dari pengambilan laporan keuangan, catatan, yang berhubungan langsung dengan masalah yang dibahas dalam penelitian, lembaga atau instansi yang terkait didalamnya.

b. Sumber Data

Sumber data penelitian ini diperoleh dari laporan keuangan tahunan periode 2015-2018 perusahaan sektor manufaktur yang terdaftar di Bursa Efek Indonesia (BEI) dengan mengunjungi situswww.idx.id.

\section{HASIL ANALISIS DAN PEMBAHASAN}

\section{Analisis Regresi Linier Berganda}

Berdasarkan Tabel 1 dapat dibuat suatu persamaan regresi untuk variabel Profitabilitas (X1), Likuiditas (X2) dan Kebijakan Dividen (X3) terhadap Nilai Perusahaan (Y) manufaktur yang terdaftar di Bursa Efek Indonesia (BEI) sebagai berikut:

$\mathrm{Y}=9.234+44.157 \mathrm{X} 1-5.447 \mathrm{X} 2+7.149 \mathrm{X} 3+\mathrm{e}$

Pada variabel Profitabilitas (X1) dan Kebijakan Dividen (X3) menunjukkan nilai koefisien regresi linier berganda positif, hal tersebut menunjukkan bahwa adanya arah positif atau adanya hubungan searah dari variabel bebas terhadap variabel terikat Nilai Perusahaan (Y), dapat diartikan bahwa jika semakin meningkatnya variabel bebas seperti Profitabilitas (X1) dan Kebijakan Dividen (X3) akan meningkatkan pula variabel Nilai Perusahaan (Y). Sedangkan pada variabel Likuiditas (X2) memperoleh nilai koefisien regresi linier berganda positif, hal tersebut menunjukkan bahwa adanya arah negatif atau 
adanya hubungan tidak searah dari variabel bebas terhadap variabel terikat Nilai Perusahaan (Y), dapat diartikan bahwa jika semakin menurunnya variabel bebas Likuiditas (X2) maka akan menurunkan variabel terikat Nilai Perusahaan (Y) dan sebaliknya.

\section{Uji Koefisien Regresi $\left(\mathbf{R}^{2}\right)$}

Nilai R Square berdasarkan hasil perhitungan dengan menggunakan program SPSS versi 15.0 sebesar 0,448 artinya $44,8 \%$. Hal ini berarti variasi variabel dependen yang dapat dijelaskan oleh variabel independen adalah sebesar 44,8\% sedangkan sisanya sebesar 55,2\% dijelaskan oleh variabel lainnya yang tidak dimasukkan ke dalam model regresi dalam penelitian ini. Sehingga dapat disimpulkan bahwa rasio Profitabilitas, Likuiditas dan Kebijakan Dividen berpengaruh sebesar 44,8\% terhadap Nilai Perusahaan, sedangkan sisanya sebesar $55,2 \%$ dipengaruhi oleh variabel lain yang tidak diteliti.

\section{Pengujian Hipotesis}

\section{Uji Hipotesis 4 (Uji F)}

Berdasarkan tabel 3, dapat diketahui bahwa Fsig sebesar $0,000<0,05$, sesuai dengan ketentuan yang telah ditetapkan. Hal ini berarti ada pengaruh Profitabilitas (X1), Likuiditas (X2) dan Kebijakan Dividen (X3) terhadap Nilai Perusahaan (Y) .

\section{Uji Hipotesis 3 (Uji t)}

Berdasarkan hasil penelitian yang didapatkan bahwa variabel Profitabilitas (X1) dan Likuditas (X2) memiliki pengaruh secara parsial terhadap Nilai Perusahaan. Hal ini dapat diketahui nilai t sig Profitabilitas (X1) sebesar 0,000 atau < 0,05, maka $\mathrm{H}_{0}$ ditolak pada tingkat signifikansi 5\% sehingga variabel Profitabilitas (X1) mempunyai pengaruh signifikan terhadap Nilai Perusahaan pada perusahaan manufaktur pada tahun 2015-2018. Nilai t sig Likuiditas (X2) sebesar 0,003< 0,05, maka $\mathrm{H}_{0}$ diterima pada tingkat signifikansi 5\% sehingga variabel Likuiditas (X2) mempunyai pengaruh signifikan terhadap Nilai Perusahaan pada perusahaan manufaktur pada tahun 2015-2018.

Hasil penelitian menunjukkan bahwa variabel Kebijakan Dividen (X3) tidak memiliki pengaruh secara parsial terhadap Nilai Perusahaan, hal ini dapat diketahui nilai $\mathrm{t}$ sig sebesar 0,098 atau > 0,05, maka $\mathrm{H}_{0}$ ditolak pada tingkat signifikansi 5\% sehingga variabel Kebijakan Dividen (X3) tidak mempunyai pengaruh signifikan terhadap Nilai Perusahaan (Y) (Tabel 4).

Tabel 3

Hasil Uji F

\begin{tabular}{llrrrrr}
\hline \multicolumn{2}{l}{ Model } & & \multicolumn{2}{c}{ Sum of } & \multicolumn{2}{c}{ Mean } \\
Squares & \multicolumn{1}{c}{ df } & \multicolumn{1}{c}{ Square } & \multicolumn{1}{c}{ F } & \multicolumn{1}{c}{ Sig. } \\
\hline 1 & Regression & 6896,735 & 3 & 2298,912 & 15,162 &, $000(\mathrm{a})$ \\
& Residual & 8490,834 & 56 & 151,622 & & \\
& Total & 15387,570 & 59 & & & \\
\hline
\end{tabular}

Sumber: Peneliti (2019) 


\begin{tabular}{|c|c|c|c|c|c|c|}
\hline \multicolumn{7}{|c|}{$\begin{array}{c}\text { Tabel } 4 \\
\text { Hasil Uji t }\end{array}$} \\
\hline \multirow{3}{*}{$\begin{array}{l}\text { Mode } \\
1\end{array}$} & & \multicolumn{2}{|c|}{$\begin{array}{l}\text { Unstandardized } \\
\text { Coefficients }\end{array}$} & $\begin{array}{l}\text { Standardized } \\
\text { Coefficients }\end{array}$ & $\mathrm{t}$ & Sig. \\
\hline & & & Std. & & & Std. \\
\hline & & $\mathrm{B}$ & Error & Beta & B & Error \\
\hline 1 & (Constant) & 9,234 & 3,998 & & 2,310 &, 025 \\
\hline & Profitabilitas & 44,157 & 11,278 & ,446 & 3,915 & ,000 \\
\hline & Likuiditas & $-5,447$ & 1,743 &,- 332 & $-3,124$ & ,003 \\
\hline & $\begin{array}{l}\text { Kebijakan } \\
\text { Dividen }\end{array}$ & 7,149 & 4,245 & , 192 & 1,684 & ,098 \\
\hline
\end{tabular}

Sumber: Peneliti (2019)

\section{Tabel 5}

Hasil Uji Dominan

\begin{tabular}{ll}
\hline Variable & Standardized Coefficients Beta \\
\hline Profitabilitas & 0,446 \\
Likuiditas & $-0,332$ \\
Kebijakan Dividen & 0,192 \\
\hline
\end{tabular}

Sumber: Peneliti (2019)

\section{Uji Hipotesis 4 (Uji Dominan)}

Berdasarkan data yang dapat dilihat pada tabel 4.4.4 diatas, terlihat bahwa nilai koefisien beta terbesar adalah untuk variabel Profitabilitas (X1) yaitu sebesar 0,446 artinya secara parsial variabel Profitabilitas (X1) memberikan pengaruh yang paling dominan terhadap Nilai Perusahaan (Y). Sedangkan yang memberikan pengaruh yang terkecil terhadap Nilai Perusahaan (Y) adalah variabel Likuiditas (X2) dengan memiliki nilai koefisien beta terkecil yaitu sebesar $-0,332$.

\section{SIMPULAN}

Berdasarkan hasil penelitian dan pembahasan, maka dapat ditarik simpulan sebagai berikut, variabel Profitabilitas (Return On Assets) berpengaruh positif dan signifikan terhadap Nilai Perusahaan dalam perusahaan manufaktur yang terdaftar di Bursa Efek Indonesia (BEI). Hal ini dibuktikan dengan hasil koefisien regresi yang menunjukkan angka positif dan tingat signifikansinya lebih kecil dari nilai signifikansi yang sudah ditetapkan. Variabel Likuiditas (Current Ratio) berpengaruh negatif dan signifikan terhadap Nilai Perusahaan dalam perusahaan manufaktur yang terdaftar di Bursa Efek Indonesia (BEI). Hal ini dibuktikan dengan hasil koefisien regresi yang menunjukkan angka negatif dan tingkat signifikansinya lebih kecil dari nilai signifikansi yang sudah ditetapkan. Variabel Kebijakan Dividen (Dividend Payout Ratio) berpengaruh positif tetapi tidak signifikan terhadap Nilai Perusahaan dalam perusahaan manufaktur yang terdaftar di Bursa Efek Indonesia (BEI). Hal ini dibuktikan dengan hasil koefisien regresi yang menunjukkan angka positif dan tingkat signifikansinya lebih besar dari tingkat signifikansi yang sudah ditetapkan. Melalui pengujian bersama-sama atau simultan, ketiga variabel yaitu Profitabilitas, Likuiditas dan Kebijakan Dividen berpengaruh positif dan signifikan terhadap Nilai Perusahaan. Hal ini terbukti dari hasil pengujian secara bersama-sama atau simultan yang menyatakan bahwa nilai signifikan menunjukkan angka 
positif dan lebih kecil dari nilai signifikansi yang sudah ditetapkan, atau bisa diartinya bahwa terbukti ketiga variabel bebas tersebut mempunyai pengaruh yang positif dan signifikan terhadap variabel terikat yaitu Nilai Perusahaan. Melalui pengujian secara dominan, dapat diketahui bahwa variabel bebas Profitabilitas dominan terhadap variabel terikat Nilai Perusahaan dikarenakan nilai signifikansi yang dihasilkan paling besar daripada variabel lainnya. Berdasarkan hasil penelitian secara keseluruhan dan simpulan yang diperoleh, dapat dikembangkan beberapa saran bagi pihak-pihak yang berkepentingan dalam penelitian. Adapun saran yang dikemukakan adalah sebagai berikut, Diharapkan perusahaan dapat lebih meningkatkan Profitabilitas agar investor tertarik untuk menanamkan sahamnya sehingga dapat meningkatkan Nilai Perusahaan tersebut. Bagi perusahaan diharapkan lebih berusaha meningkatkan kemampuannya dalam melunasi hutang jangka pendeknya serta meningkatkan nilai dalam pembagian dividen. Bagi peneliti selanjutnya diharapkan dapat melanjutkan penelitian ini dengan variabel-variabel lain diluar variabel yang telah diteliti dan menambahkan sampel perusahaan agar dapat memperoleh hasil yang lebih bervariatif yang berkaitan dengan Nilai Perusahaan.

\section{DAFTAR PUSTAKA}

Erawati, Dedi Sulistiyanto, 2019. Pengaruh Struktur Modal, Profitabilitas, Likuditas, Dan Tax Avoidance Terhadap Nilai Perusahaan. Jurnal akuntansi pajak dewantara. Vol. 1 No. 1. Universitas Sarjanawiyata Tamansiswa. Yogyakarta.

Hanafi, Abdu Halim, 2016. Analisis Laporan Keuangan. Edisi Kelima. UPP STIM YKPN, Yogyakarta.

H. Manoppo., F.V. Arie. 2016. Pengaruh Struktur Modal, Ukuran Perusahaan Dan Profitabilitas Terhadap Nilai Perusahaan Otomotif Yang Terdaftar Di Bursa Efek Indonesia Periode 2011-2014. Manajemen. Fakultas Ekonomi dan Bisnis. Universitas Sam Ratulangi Manado. Manado.

Sujarweni, Wiratna V. 2017. Manajemen Keuangan Teori, Aplikasi Dan Hasil Penelitian. Pustaka Baru Press. Bantul. Yogyakarta.

Susila, I Made Pradnya, Gine Das Prena. 2019. Pengaruh Keputusan Pendanaan, Kebijakan Dividen, Profitabilitas, Dan Corporate Social Responsibility Terhadap Nilai Perusahaan. Vol 6 No. 1. Universitas Pendidikan Nasional Denpasar. Bali. 